\title{
Margaret McCartney: Evidence based protest for the NHS
}

\author{
Margaret McCartney general practitioner
}

Glasgow

England's junior doctors are planning more strikes. I hope that, in the High Court in September, the Justice for Health campaign succeeds in finding that the health secretary has no power to impose a contract. If not, the dispute will smoulder. Much public sympathy is still likely, but parts of the media will be predictably hostile.

The new contract is unfair. It relies on misinterpreted statistics surrounding the so called weekend effect. But this is only a part of the current mess in medicine.

Staff are stressed. Services are being cut. The joy of medicine is still there but in scarce supply. Failing to find enough pleasure in work leads to staff cutting their hours or retiring early, leaving more gaps in the system.

The government is not spending enough on the NHS. Much of what is spent is wasted on short term, non-evidenced, political policies that drain resources in the longer term, such as health checks. The founding principle of the NHS - that it is free at the point of use, according to need - is being challenged because of political weakness and repeated non-evidence based policy making, which harms us all.

Stopping doing things that waste our time will benefit patients - and if it causes political inconvenience, so much the better

Junior doctors are right to take action, but they need to keep broad support while being able to explain to the public how it is that the NHS is being allowed to fail. I'm not a medical politician or tactician, and others will have better ideas. But we need a protest that involves all doctors, which is sustainable, and which will not harm (and may even benefit) patients. It should harm only the political policy making that damages the NHS.

What could our protest be? Appraisal consumes a vast amount of time and adds little value to many doctors' ability to care for patients: could we refuse to do more than is clinically useful? Care Quality Commission inspections cost a fortune and are of questionable value: we should negotiate for inspections based only on evidence and should refuse to take part in wasteful paperwork.

We need better, united action that makes it clear to the public that professionals are still motivated by vocation but that we can't do our jobs well given dwindling and misspent resources. Stopping doing things that waste our time will benefit patients - and if it causes political inconvenience, so much the better. A highly visible, evidence based, online campaign could make the facts known and explain what we need to keep the NHS sustainable.

I'd bet that most of the population would be willing to spend more on front line services in the NHS. We are not being given that option.

Competing interests: See www.bmj.com/about-bmj/freelancecontributors/margaret-mccartney.

Provenance and peer review: Commissioned; not externally peer reviewed.

Published by the BMJ Publishing Group Limited. For permission to use (where not already granted under a licence) please go to http://group.bmj.com/group/rights-licensing/ permissions 